\title{
Nation-state Legitimacy, Trade, and the China Investment Corporation
}

Gordon L Clark+ and Ashby H B Monk School of Geography and the Environment, Oxford University Centre for the Environment, South Parks Road, Oxford OX1 3QY, United Kingdom; also +Faculty of Business and Economics, Monash University, Caulfield 3145, Victoria, Australia

\section{Contact. gordon.clark@ouce.ox.ac.uk}

Abstract. Relations between China and the USA began with the best of intentions: the USA would sponsor the normalization of China's status in the international community through trade in exchange for China's commitment to peaceful coexistence with the west. As an emerging economy, China has relied upon trade for export-led economic growth, mimicking the path taken by its immediate neighbours over the past 25 years and the road taken previously by Germany and Japan. For a variety of reasons, the original deal has been over-taken by the massive surge in Chinese exports to the USA, the tensions occasioned by the global financial crisis, and the sense in which the USA, as a debtor country, is now reliant upon China for its long-term future. The China Investment Corporation (CIC) is a product of the original deal and is emblematic of the new status of China in the global economy. As one of the world's largest sovereign wealth funds, the CIC has eschewed conventional portfolio investment in developed financial markets for strategic investment in resources and jurisdictions deemed essential to China's long-term growth. As such, attempts to rein-in its ambitions through the Santiago Principles and the like have been circumvented by a very different approach to investment. The CIC is re-making the rules of engagement in global financial markets, thereby redrawing the nature and scope of the long-term relationship between the two superpowers of the twenty-first century: China and the USA.

Keywords. Trade, China, imbalances, global investment

JEL Codes. G23, G24, L12

Acknowledgements. This paper was made possible by the support of the Leverhulme Trust for our project on the governance and performance of sovereign wealth funds. It bears the imprint of comments on previous drafts by Jiazhe Sun and Rien Huizer, and the assistance of Olga Thönissen, and the views and opinions of a number of respondents including those from the China Investment Corporation. The views and opinions expressed herein are those of the authors and do not bear upon any institution or its officials. 


\section{Introduction}

As the global financial crisis accelerated through the second half of 2007, the newly established Chinese Investment Corporation (CIC) took a \$US5 billion stake in Morgan Stanley. Like many other US institutions, Morgan Stanley was vulnerable to the discounting of its mortgage (subprime) investments and rapidly eroding confidence in its capacity to withstand the rigors of market volatility. In exchange for the CIC’s investment, Morgan Stanley gave up nearly 10 per cent of its common stock. With other, similarly high profile, investments in Blackrock and JC Flowers, the Chinese government announced, in effect, that its new found wealth would be used to claim a share of the global financial industry. Still, it could be argued that these investments were premature, being indicative of the immature nature of CIC investment decision-making in the face of market uncertainty. Another 24 months were to pass before markets rallied and there was some semblance of market confidence in the US and the global banking industry.

American response to these investments was muted when compared to the hostility shown to proposed investments by Middle Eastern sovereign wealth funds in US infrastructure a couple of years prior to the financial meltdown. ${ }^{1}$ In some quarters, it was hoped that the CIC and other large sovereign wealth funds might underwrite global financial stability, using their deep pockets to take long-term positions in the core institutions of the global economy. It was also hoped that these investments and government-led initiatives to stabilise financial markets might forestall a deeper crisis, one that threatened to fracture the global hegemony of the Anglo-American system of financial intermediation and market exchange. These hopes were not realised. As the crisis deepened in 2008 the newly-established CIC faced growing domestic (Chinese) public pressure to justify its investments. The CIC, like most other large sovereign wealth funds that had been established in the later years of the decade, retreated to the sidelines of western markets. Instead, the CIC has favoured strategic investment, focusing upon the Chinese banking industry and global resource sectors--its long-term perspective 'regulated' by government concern to secure Chinese economic development.

\footnotetext{
\%. See Cohen (2009, 719-20) for commentary on the concerns of US and European governments about the intentions and effects of sovereign wealth funds particularly with respect to their direct economic consequences and their more subtle indirect consequences on foreign policy-making and security.
} 
Like most sovereign wealth funds, the CIC's assets derive from foreign earnings. For example, the assets of the Norwegian NBIM, the Middle Eastern SWFs, and the Australian Future Fund are based wholly or in large part on their nation-state sponsors' natural resources whether directly (through state-owned enterprises) or indirectly (through tax receipts on resource extraction and trade) (Clark and Monk 2010). By contrast, the CIC's assets are not owed to natural resources and the opportunity to charge a scarcity premium in the global marketplace. The CIC's assets derive from the accumulated dollar-denominated foreign currency reserves held by the Chinese government due to the export of consumer products by state-owned enterprises and western corporations to developed economies' consumer markets. In this respect, the CIC's assets are derived from the growth in trade between China and the west over the past couple of decades and, in particular, the decision of the US government to 'normalise' trading relations with China in 1980 and to seek to make 'permanent' this arrangement in 2000.

In opening the world's largest consumer market to Chinese exports, the US provided the opportunity for Chinese economic development hitherto missing in the suffocating relationship between the USSR and the People's Republic of China. Trade between China and the US grew at astonished rates over 1990 to 2000 and 2000 to 2009, far surpassing informed expectations (including those of the US Senate committee that agreed to the designation of permanent normal trade relationships). By 2009, the yearly net value of US trade for China was worth approximately $\$ 350$ billion and the value of accumulated US dollar-denominated foreign currency reserves were more than \$2 trillion. When established, the Chinese government allocated the CIC \$200 billion by issuing a special bond underwritten, at least informally, by foreign reserves. By our account, American consumers made the CIC possible; that it played a role in initial attempts at stabilising US financial markets and banks could be seen as an appropriate reciprocal gesture of support for an ally in trouble. ${ }^{2}$

\footnotetext{
$\%$ Of course, it may be a more complicated story. For instance, informed observers have noted that the investment in Morgan Stanley came before the US government through the Board of the Federal Reserve System approved in August 2008 the request from the CIC to be exempted from the US Bank Holding Company Act that limits investment in nonbanking companies. See the letter dated August 5, 2008 from Frierson, Deputy Secretary of the Board to Cohen of Sullivan and Cromwell (New York).
} 
We explore the nature of the "deal" that was struck when American markets were opened up to China. While commercial advantage in a growing market was clearly important, we note that for some Democratic members of Congress the deal was also predicted upon a Chinese commitment to the norms and conventions of the international community of nations. In effect, the origins of the CIC can be found, in part, in an American commitment to "normalise" China's role in the global economy, linking trade with expectations about political freedoms and international conventions on labour standards etc. So, in the first instance, nation-state legitimacy and economic development through American trade policy were closely aligned. However, we also review recent research that emphasises the costs and consequences of Chinese development policy and in particular its reliance upon export-growth pegged to the US dollar. Taking the argument forward, we suggest that the debate about sovereign wealth fund disclosure and transparency initiated by Washingtonbased think tanks can be seen as an expression of an impulse to "normalise" the institutions and governance practices of other countries from a position of strength (Truman 2007).

The paper begins with the issue of state legitimacy broadening its ambit from the principles and practices of policy making to the relations between nations. If this reference point could be deemed somewhat "idealist” in character, it should be noted that, at base, our perspective on the relations between China and the USA is fundamentally realist in conception and interpretation. ${ }^{3}$ We draw upon debate in the US Senate to explain the nature of the 'deal' struck with China and the expectations of US policy makers as regards the terms of 'normalisation'. This is followed by a brief account of China-USA trade and the reliance of China on a dollar-pegged exchange rate-in this respect, the resulting 'imbalances' in trade and the formation of the CIC can be seen as expressions of China's neo-mercantilist commitment to

\footnotetext{
$3 /$. Realist perspectives on international relations have been subject to widespread debate and criticism over the past few decades (Brooks and Wohlforth 2008). If conceived in terms of the cold-war and competition for global dominance, realism has affinities with the literature on imperialism and empire (see Callinicos 2009). Here, our stance is more nuanced, albeit based upon national interest (at least from the perspective of China). Legitimacy can be treated as an expression of power-the prerogative of the hegemon. But, inevitably, legitimacy is also a strategy with rhetorical and bilateral dimensions best not collapsed into hypocrisy (Runciman 2008).
} 
national economic growth. ${ }^{4}$ If this now appears to be at odds with US expectations at the time the deal was struck in the Senate, it reflects, we believe, $21^{\text {st }}$ century realities of global financial power.

\section{Nation-state Legitimacy}

The intimate economic and political relationship between China and the USA would surely be judged a surprising turn of events by Cold War warriors of the 1950s and early 1960s. Some 50 years ago or so, the Chinese communist revolution combined with the uneasy stand-off with the USSR in continental Europe in the aftermath of the Second World War framed international relations between nation-states-from sport, to trade, to cultural exchange, and to military expenditures the world was divided into two camps one centred on the United States and the other centred on the USSR. This bipolar map of the world was understood in simple ideological terms as a competition between capitalism and communism, thereby framing what counted as acceptable economic institutions through to political and social aspirations. Inevitably, diverse traditions and institutions amongst nations as well as rivalries and tensions between countries within these two blocks were largely ignored in this simple conceptualisation of cold war politics (rediscovered 50 years later by economic geographers and political scientists through "path dependence" and the "varieties of capitalism"; see Clark and Wójcik 2007 and Hall and Soskice 2001).

In the west, capitalism was judged legitimate and communism judged illegitimate in the sense that the former was believed consistent with the values of liberal democracy whereas the latter was conceived in terms of authoritarianism and totalitarianism. This simplistic bipolar conception of the world was exploded by President Richard Nixon when he surprised the American public and its' allies by visiting China in February 1972. In doing so, the simmering rivalry between the USSR and China over border-demarcation, regional insurgency, and leadership of the communist bloc was given expression in rapprochement with the west (see Kissinger 1982 for a detailed exposition of these issues). For the American public, it was now possible for nation-

\footnotetext{
4. Much has been written about Asian neo-mercantilism as a strategy of export-led economic development (see Clark and Kim 1996). Like Calleo (2009, Ch.6), we would suggest that there is an intimate relationship between state power and mercantilism in that the later tends to underwrite the former especially in one-party states that link patronage and privilege with 'official' positions inside and outside of government. We develop this point below with respect to the governance of the CIC.
} 
states to have specific interests which went beyond being members of one bloc or the other; the USA and China could agree to co-operate, discounting a rigid conception of a divided world. Nixon's visit to China suggested that countries need not share the same ideological commitments to be accepted into the international community of nations. Coming almost 20 years before the Iron Curtain literally crumbled into disarray, the USA could offer Chinese leaders entree into the international community separate from the United Nations and the USSR.

On offer was the option to join the international community and its established systems of cooperation, commerce, and negotiation. Nonetheless, it would take another 30 years before China joined the World Trade Organisation (WTO), sponsored by the USA. By the time the Berlin Wall was taken apart brick by brick by Germans seeking to reunite with the political traditions of western Europe, China had found its way to economic co-operation with the United States and, crucially, status as one of a number of nations accorded normal trade relations. ${ }^{5}$ That is, the right to export to the single largest consumer market in the world. Few at the time (1990) would have imagined that the right to trade with the USA would figure so significantly for Chinese economic development and for the hegemony of the USA in the early 21st century. It is remarkable that it took an investment bank, Goldman Sachs (2001), to recognize that China along with Brazil, Russia and India (the 'BRICs') would effectively reshape the structure of the global economy through the 21st century, undercutting the role and significance of the United States as the global superpower of the second half of the 20th century.

Suggested by this brief recounting of the evolution of China-USA relations are three points of mutual interest: the formation of a sphere of cooperation distinct from USAUSSR relations, a role for China in the international community even if limited to mutual tolerance if not respect, and the opportunity for China to trade with the rest of the world. In this sense, as befitting its power in the global economy, the USA conferred on China a rudimentary form of legitimacy: in effect, international

\footnotetext{
5 . The reasons for European re-integration and the putative failure of the Russian empire are many and varied. It is important to acknowledge that the economic failure of the 'east' was as much the cause of re-integration as liberal democracy was the beacon for eastern European aspirations. As Scharpf (1999) noted some time ago, the fragility of western European democratic traditions and the limited depth of economic prosperity have undercut the legitimacy of liberal capitalism.
} 
acceptance that China was 'entitled to participate in international relations' paraphrasing Ian Clark's $(2005,2)$ statement about the relevance of the concept of legitimacy to international relations. No doubt, the reasons for the 'normalisation' of China's international status had more to do with cold war geopolitics than mutual respect and tolerance for apparent cultural, political and social differences. As such, 'normalisation' can be interpreted through a realist framework as is suggested by many US international relations specialists.

Ian Clark notes, however, that the idea that nation-states may be deemed legitimate by virtue of their participation in the international community often carries two further implications or expectations. Most generally, by invoking the existence of an international community, the implication is that there are established systems of representation, collaboration and negotiation that bind members of the community together whatever their material and ideological differences. More particularly, continuing with the analogy, it is assumed that there are certain shared norms and customs that effectively 'regulate' or 'govern' the relations between members of the international community, including reciprocity and bilateral cooperation. The analogy wears thin, though, when it comes to the issue of affecting sanctions for violating accepted modes of cooperation and the norms and customs of behaviour: how are norms and customs to be enforced? See Cohen's (2009, pp. 726-27) recounting of precisely this point applied to sovereign wealth funds. Consistent with its sense of mission, the USA has 'policed' the international community, using access to the US consumer market as a conformance incentive (Calleo 2008).

To illustrate, consider the history of China-USA trade relations through the medium of what was known as Most Favoured Nation (MFN) status or what is now termed as Normalized Trade Relations (NTR) status. As is well-appreciated, this status confers on designated countries the right to trade with the USA without being subject to discriminatory taxes and tariffs on exports to the US market. In brief, China's MFN status was "suspended" in 1951 and then restored in 1980 subject to annual renew and “compliance” with the Jackson-Vanik amendment that required China's observance with certain conditions on emigration, as well as "a bilateral trade agreement between the two countries" (Pregelj 2001, summary). Over the years, US presidents were able to renew China's MFN trade status and, for a number of years, obtain waivers on the 
Jackson-Vanik requirement. In the aftermath of the 1989 Tiananmen Square revolt, however, Congress sought to revoke MFN status but was unable to over-come the presidential veto. For many Democrats and NGOs, the annual review was an occasion to press for extending the terms and conditions of China's trade status to include human rights and labour standards-some of the shared norms that arguably bind nations together in an international community (see Brannelly 2002).

If often debated, these considerations were, more often than not, set-aside in favour of 'free trade'. ${ }^{6}$ In testimony before the Senate Commerce committee, an NGO representative put the issue succinctly: "are we going to have a commercial policy or a broader relationship that looks at the national interest" and "the zeal to do a policy with China (that) suits companies that want to relocate investment to China and guarantee permanent, unconditional access back into the US” (April 11, 2000, page 69). The deal struck between the Clinton Administration and China over trade linked US support for China's accession (in 2001) to the WTO and Congressional approval of Permanent Normalized Trade Relations (PNTR). ${ }^{7}$ Here, the Republican Chairman of the Senate Commerce committee John McCain argued that accession to the WTO and PNTR would be powerful US levers on the Chinese government to adopt tariff reforms, approve foreign investment, and protect intellectual property. He also suggested that WTO membership would undercut the dominance of the communist party and that greater “transparency and reforms are the price of China's entry into the global trading system.” He went on to link the China-USA trade relationship to the reform of human rights and labour standards.

\footnotetext{
\%. See Xie (2006) on a study of voting in the House and the Senate for most favoured nation status and permanent normal trade relations where it is shown that party differences and an ideological commitment to free trade dominated voting such that domestic economic and political interests were often marginalised.

\% . The precise terms of this 'deal' remains subject to debate. As public debate over the issue gathered momentum in late 1999, the Chinese government through its US Embassy spokesman indicated that the 'deal' with Clinton was binding in that WTO status without PNTR status was unacceptable given the concessions made by the Chinese government on tariffs and the like. Much of the debate seemed to centre on the interpretation of Clinton's “commitment” and whether PNTR was actually relevant once China was accepted into the WTO. See, the commentary provided by Lori Wallach in her submission to the Hearing before the Senate Committee on Commerce, April 11, 2000, pp. 87-88.
} 


\section{Neo-Mercantilist Economic Growth}

If Senator McCain (R-Arizona) was confident that China was willing to pay the "price” for normalization, Senator Hollings (D-SC) was not so sure. In his testimony and written statement, Hollings rehearsed the case for free trade and focused upon the costs and consequences of that policy for the welfare of US communities dependent upon labour-intensive industries (such as textiles in South Carolina). He noted that the standard free trade argument assumes the composition of trade changes as the low-skill labour intensive industries of developed economies (USA) shift off-shore, replaced by highly skilled capital intensive industries that claim their share of the global marketplace. With increased economic growth due to the efficiency-premium on the geographical dispersal of production and exchange, employment growth should compensate for local job losses. For Hollings, the plausibility of this process depends upon developing countries being willing to take-up their share of exports from the developed world-something he doubted. ${ }^{8}$ Invoking the Japanese case, he believed China would not honour their side of the deal. He forecast that the Chinese trade surplus with the US of $\$ 68$ billion would "spiral out of control” should the PNTR initiative be accepted. ${ }^{9}$

By contrast, Senator Ashcroft (R-MO) commended the Secretary of Commerce for having negotiated the trade agreement with China and supported the passage of the PNTR. He noted that firms and industries from Missouri stood to gain from the agreement, including manufacturing and agricultural firms that could claim their share of global markets. Access to the burgeoning Chinese market was the obvious benefit of the agreement; a point echoed by Senator Bryan (R-NV) who believed that, whatever the abuses of human rights, access to the Chinese market trumped all other considerations. Nonetheless, Ashcroft did raise concerns about whether China would comply with the terms of the PNTR and the conditions associated with accession to the WTO. In his testimony, the Commerce Secretary (William Daley) argued against

\footnotetext{
8\% But see Bown (2010) on the reasons why China sought WTO accession, arguing that it also faced significant barriers to the export of goods including impediments imposed by developed economies such as Australia, Canada, the EU and the US and those imposed by developing economies such as India, Argentina and South Africa.

$\%$. At the time, it was widely believed that the growth of Chinese exports to the USA would be modest and would be accompanied by lower Chinese tariffs on imported goods. Hollings' prediction was wellbeyond the bounds of conventional expectations (see Saaty and Cho 2001).
} 
Hollings suggesting that there was, in fact, no leverage to be had over China in annual reviews and that, in any event, the agreement with China contained "strong enforcement mechanisms and strong protections against unfair trade” (April 11, 2000, page 14).

It turns out Hollings was correct. After 2001, the terms of trade exploded in China's favour, with exports to the USA accelerating far-beyond conventional expectations reaching nearly $\$ 300$ billion in 2007 (just before the on-set of the global financial crisis) (Figure 1). Reasons for the explosion in Chinese exports over the first decade of the $21^{\text {st }}$ century are many and varied. ${ }^{10}$ Most obviously, growth in the volume of exports reflected official Chinese development policy mimicking, in part, the earlier success of the Asian newly industrialised economies (NIEs) of Hong Kong, Korea, Singapore and Taiwan in using exports to the west as the engine of growth (see Chow and Kellman 1993; IMF 1993). However, in a study of the economic forces shaping the success of the Asian NIEs, Webber (1996) argued that the initial massive imbalance between exports and imports that marked the first phase of NIE growth would soon pass. In the second phase of development, imports essential to production should rise to match exports; equally, as labour resources become increasingly scarce, increasing real wages should prompt increasing demand for western consumption goods.

\section{[INSERT FIGURE 1 ABOUT HERE]}

By this logic, Figure 1 reflects the first phase of Chinese development. Note, though, that two other factors should also be taken into account. Sustaining the growth in exports to the USA was the Chinese government's policy of pegging the local currency (RMB) to the US dollar with a fixed exchange rate. In Figure 2, we display the temporal pattern of the major currencies against the US dollar since 1994. For the

\footnotetext{
10 . The growth and composition of Chinese exports has been the subject of considerable research; see, for example, Amiti and Freund (2010) who show that over the period 1992 to 2005 Chinese exports became more capital intensive, specialised, and reliant upon the processing of intermediate goods. Grossman and Helpman (2005) and Grossman and Rossi (2008) provide a useful theoretical treatment of the fragmentation of international trade around tasks and functions as opposed to final goods while Dean and Lovely (2010) reference the relevant empirical literature and demonstrate the significance of the issue for Chinese trade and environmental policy.
} 
most part, governments have been willing to let currency markets set currency rates, reflected in the volatility and trends in currencies against the US dollar. For the RMB, however, the Chinese government has sought to fix the US dollar exchange rate (see 1995-2005) and sought to manage currency appreciation against a basket of currencies, in particular as exports to the US exploded in volume and value post 2005. In effect, China's currency regime has been used to enhance its claim on US consumer markets against Europe and Japan while holding firm the price advantage enjoyed by exporters to the US relative to US domestic producers. ${ }^{11}$ As such, it has been a policy designed to hold in abeyance the immutable forces of economic correction inherent in the export-led model of growth (see Stiglitz 2009, pp. 228-29).

\section{[INSERT FIGURE 2 ABOUT HERE]}

Not only did this policy accelerate the growth in the trade surplus with the US, in the context of the global financial crisis, holding firm to such an absolute trade advantage, China risked protectionism or even a trade war with the west. Goldstein and Lardy (2006) suggest that this policy has contributed to internal problems of macroeconomic stability including wage-price and property-price inflation. By limiting currency appreciation in the context of the burgeoning demand for imports of raw materials from countries such as Australia, China has lost an opportunity to discount the costs of those commodities, as the Australian dollar (amongst a number of other country currencies) appreciated against the US dollar. ${ }^{12}$ They also suggest that this policy has been pursued to protect the domestic banking system from the possible consequences of currency revaluation for fixed asset values, exchange-rate speculation, and capital flight. We return to this issue in the next section. Through its subsidiary Central

\footnotetext{
11\% Reporting on the undervalued RMB, Goldstein and Lardy (2006, $423 \mathrm{ftn}$. 2) suggested the RMB was undervalued against the US dollar in 2005 by as much as 43 per cent. There have been other estimates, and techniques for determining the extent of under-valuation (see Bowles and Wang 2006). See also Cheung et al. $(2010,232)$ for an analysis (end 2008) where they concluded that the RMB may be undervalued by as much as 50 per cent although they also note that this estimate may not be statistically robust given mean estimates and sensitivity to "substantial revisions to the underlying data." More recently, Goldman Sachs (2010) suggested that the RMB "no longer seems strongly undervalued (against the US dollar)" but suggested that it may be "'revalued' in a one-off move, and then allowed to trade in a wider band, perhaps being truly managed on a trade-weighted basis."

12 . See Garton and Chang's $(2007,85)$ assessment of the so-called liberalisation of China's currency peg regime since 2005 and their conclusion that "in practice, the bilateral US dollar rate has continued to be tightly managed and further RMB appreciation against the (US) dollar has so far been limited.”
} 
Huijin, investment to shore-up the stability of the domestic banking system has been one of the most important commitments made by the CIC.

Informed commentary on the issue has been split on whether the dollar-peg is sustainable, whether it has significantly distorted the Chinese economy, and whether it is likely to persist. As well, it has been noted that China is hardly the only country to have pursued such a growth strategy (see Reinhart et al. 2003). Dooley et al. (2004) suggest, in fact, following the Second World War in reconstruction, Germany and Japan also pursued a dollar-peg economic growth policy aided and abetted by the US government. More generally, Dooley et al. suggest that this policy tends to run its course such that established dollar-peg economies will eventually move from the periphery of the world economy to the core of the world economy wherein their own currencies become 'partners' with the US dollar in underwriting foreign trade and exchange. In their potted history of the world, it is assumed that dollar-peg economies buy US securities in part to 'manage' official currency exchange rates and in part to underwrite the resulting gross imbalances in trade between dollar-peg economies and the USA. There is, then, a reciprocal relationship between Dooley et al.'s core and periphery model of neo-mercantilism (see also Aizenman and Lee 2008 on the age-old notion of mercantilism applied to sovereign wealth funds as a $21^{\text {st }}$ century mechanism for hoarding capital). ${ }^{13}$

However, 'reciprocity' was thrown out-of-equilibrium during the first decade of the $21^{\text {st }}$ century (contra the suggestion of Xafa 2007 that these imbalances are, or were, in some sense 'sustainable'). Most obviously, the massive growth of Chinese exports to the US economy after 2000 began to affect the capacity of the US government to control its own destiny-compared to Germany and Japan immediately after the second world war, the rapid growth of the Chinese economy threatened to over-turn the core-periphery relationship before the 'periphery' was economically mature and willing and able (in a regulatory sense) to float its own currency. As well, expansionary macroeconomic policy combined with the unrestrained growth in

\footnotetext{
$13 \%$ This logic, although instructive, does elide significant differences between countries. So, for example, it is arguable that Germany and Japan had little choice in the matter-the US was, after-all, the dominant occupying force and set the terms of post-war reconstruction. By contrast, it is arguable that China has deliberately sought the dollar-peg as part of its geopolitical strategy of redrawing its alliance with the USSR.
} 
household indebtedness produced a surge in US demand for consumer goods that China was only too willing to meet, whatever the short-term costs in terms of its own macroeconomic stability. As such, the surge in imports could be seen as a reflection of US monetary policy making and household indebtedness (Taylor 2009), and a willingness to postpone on both sides of the Pacific the inevitable re-adjustment for short-term political purposes (see Bordo 2005; Truman 2005; and Summers 2006). ${ }^{14}$

The intertwined nature of these issues was obvious when US policymakers sought to affect the trajectory of the global financial crisis: in effect, the cumulative effects of China-US trade limited the options available to US policymakers. However, unlike some commentators, we do not believe that trade 'imbalances' per se caused the global financial crisis (i.e. unsustainable US demand for consumer goods paid for by massive inflows of capital to the US to cover the ever-widening trade imbalances). But we do believe that the massive surge in US imports of Chinese goods in the leadup to the financial crisis undercut US policymakers' expectations of realising the 'proper' relationship between the USA and China based, as it was, on US sponsorship of China in the international community (exemplified by China's membership of the World Trade Organisation).

\section{Funding and Governance of the CIC}

The relationship between trade, foreign earnings, and the funding of the CIC is more complicated than may appear to be the case. To explain, imagine that a US-based company places an order with a Chinese supplier (through a network of intermediaries, whose presence we will ignore for the moment) to deliver a ship-load of consumer products destined for the US market at a certain (dollar) price. ${ }^{15}$ Whether upfront or on consignment, fulfilment of the order means that the US company must purchase

\footnotetext{
14\% Elsewhere, Cooper (2007) explains how and why foreign investors are (were) willing to continue to underwrite the US economy referencing the preference for security of investment over the risks associated with investment in other jurisdictions with less secure institutions. Obstfeld and Rogoff (2005) look in detail at the issue of high household indebtedness.

15 . The ownership of exporting firms is an important topic. Blonigen and Ma (2010, Fig 12.3, p. 488) show that foreign-owned firms (often owned by ethnic Chinese from other countries in east Asia) have claimed a large share of increasing Chinese exports. They also show, though, that Chinese state-owned enterprises and privately owned enterprises claim as much as 40 per cent (2005) of Chinese exports. Joint ventures are not nearly as common as perhaps assumed by western commentators. The Wall Street Journal (March 18, 2010, p. A18) suggested that the political debate over the value of the RMB ignores the fact that "much of this (trade) deficit is intra-company trade, with US companies outsourcing production to China”.
} 
RMB to pay the Chinese company at the going exchange rate. A single transaction is unlikely to move-the-market. But as the volume of similar transactions grows, the pressure on the RMB also grows such that selling dollars and buying RMB changes the exchange rate in favour of the RMB (it becomes relatively more expensive). Of course, this has two benefits for those that hold RMB: it makes imports to China relatively less expensive and, in effect, it increases the real value of wages paid to Chinese workers. For the Chinese, it also makes it harder to sell Chinese goods in the US market, undercutting the value of an export-led development policy and placing a premium on local labour productivity and domestic consumer demand (Stiglitz 2009).

For an immature economy such as China, subject to inflation and the problems of mobilising and allocating financial assets to the real economy, one solution is to maintain an official exchange rate (dollar peg) and defend that exchange rate by buying US securities. ${ }^{16}$ To purchase dollar-denominated securities, the Chinese government has been printing money and offering RMB-denominated bonds to the Chinese market. Printing money without 'steralising' its effects has the potential to amplify domestic inflation while the purchase of dollar-denominated securities can be helpful in containing domestic inflation in that the collected assets are spent overseas. One way or the other, China faces strong short-term incentives to purchase dollardenominated assets. If it was simply a matter of protecting China's trade position of 2000, the accumulation of foreign reserves may have been manageable against the 'terms and conditions' of its WTO and PNTR status. However, the loose-money policies of the US Fed in the aftermath of 9/11 meant that the Chinese government, in effect, had to play a 'catch-up game' with the unchecked US demand for imported consumer goods.

\footnotetext{
16\%. Here, we use the term 'immature' in a manner consistent with King and Levine's (1993a, 735) argument to the effect that financial development is an important ingredient in promoting economic efficiency and growth. They conclude by suggesting that "the data are consistent with the view that financial services stimulate economic growth by increasing the rate of capital accumulation and by improving the efficiency with which economies use that capital.” This argument is developed in their related paper on the relationship between financial development and innovation (King and Levine 1993b). See Liang and Teng (2006) contesting the applicability of this model to China, and Deidda and Fatouh (2002) and Huang et al. (2010) who suggest, respectively, that the relationship may be nonlinear and affected by inflation (itself a proxy for the maturity of banking institutions and policy making).
} 
In some countries, sovereign wealth funds are the 'deposit' accounts for 'excess' foreign earnings (relative to the size of the domestic economy); see, for example, the Australian FF, the Norwegian NBIM, and the Singapore GIC. For China, the nominal allocation of assets to the CIC has been relatively modest in relation to the accumulated value of foreign reserves and there are other institutions such as the China Development Bank that hold the assets domestically and internationally. Unlike many other sovereign wealth funds, the CIC is not intended to be the 'investor of last resort' underwriting the autonomy of the nation-state in relation to the uncertainties of global financial markets and the potential intrusion of the International Monetary Fund into domestic affairs (Clark and Monk 2010). Given the size of Chinese foreign reserves and their investment in US dollar-denominated gilts, China's place in global financial markets is one of a number of issues that are boundup in the bilateral political and economic relationship with the United States. Like other countries' SWFs, however, the notional mandate of the CIC is to operate as the government's investment agency with special reference to the government's "excess" international reserves and global interests.

Even so, care should be taken not to over-estimate the CIC's functional autonomy and the operational significance of its mandate. Consider the logic embedded in Clark and Urwin's (2008) model of best-practice investment: there, we assume that any effective investment institution has a properly defined mandate with a delegated sphere of responsibility consistent with realising that mandate. We suggest that mandates are most effective when translated into a target rate of return or some similar goal or set of goals that have well-defined time horizons such that they can be used to rationalise the inevitable internal conflicts and disagreements over the most appropriate investment strategy. We have noted that this framework has been used in a number of sovereign institutions to enhance institutional transparency and accountability. Nonetheless, this assumes that government should be conceived of as a set of goaloriented agencies and institutions with boards of directors and managers whose roles and responsibilities are thought out in relation to those mandates. If representative of western principles of 'good government', functional efficiency is not a complete explanation of the form and functions of many institutions (compare Clark and Urwin 2008 with Merton and Bodie 2005). 
The distinction drawn here is between the formal statement of the CIC's mandate and its corporate governance, and the place of the CIC in the structure of the central government. Formally, the mandate of the CIC's board includes approving investment strategy, its implementation, the appointment of management and the delegation of tasks to managers, and reporting to the State Council. In fact, the Chairman and CEO, and Deputy CEO of the CIC are in constant contact with senior officials of the National Development Reform Commission (NDRC), the Ministry of Finance, and the State Administration of Foreign Exchange (SAFE) responding to government, reporting on actions taken, and negotiating investments in response to government policy. ${ }^{17}$ They owe their careers to the Party and government, just as board members owe their current roles and responsibilities and future opportunities to the Party and government. As for the Executive Committee, they also owe their careers to the Party, and act in accordance with their roles and responsibilities, in the first instance accountable to the Chairman and CEO but ultimately accountable to the central government. By this logic, the decisions taken by the CIC are the result of compromise and consultation amongst the various government institutions involved.

\section{[INSERT FIGURE 3 ABOUT HERE]}

Figure 3 provides a schematic description drawn from the CIC's (2008) Annual Report. There the relationship between the Board, the Executive Committee and the CEO are arranged in a manner that seems to suggest a corporate governance structure consistent with Anglo-American expectations; that is, the CEO is responsible to the Board which has the authority and responsibility to hire and fire the CEO. As suggested above, however, this formal arrangement does not accord with the substantive arrangement of powers and the intimate relationship among the CEO, the Board, and the central government. In a similar way, the Board of Supervisors, which appears parallel to the Board of Directors, may have more symbolic significance than substantive powers. Notionally, the Board of Supervisors brings together 'stakeholders' from related and over-lapping central government institutions. If similar in form to continental European conceptions of corporate supervisory boards, it is less obviously an entity of significance in terms of the CIC's relationship with

\footnotetext{
${ }^{17} \%$ See Hu (2010) for an account of the significance and status of SAFE.
} 
government ministries than it is one expression of the central government's concern to underwrite the internal legitimacy of the CIC.

By this account, central government directly and indirectly influences CIC decisionmaking, notwithstanding the skills and qualifications of the financial specialists that are notionally responsible for its operational performance. ${ }^{18}$ In contrast to other accounts of the structure and management of the CIC, we have suggested that central government is able to sustain control of the CIC by virtue of the Party's claim on the career prospects of senior officials and the over-arching importance attributed by the Party to Chinese economic growth (and all that is implied in terms of China's geopolitical status). This does not necessarily mean that bureaucratic conflict is neutered by Party incentives; there are, of course, various factions that co-exist and compete for power in central government, in its administrative units, and in StateOwned Enterprises (SOE) (see Eaton 2009 and Koppell 2007). As in many other countries, negotiation and agreement are essential elements in policy making. But this account does help understand how and why the CIC's supervisory board is functionally less significant than it may appear by virtue of the formal structure of management. Whatever its role in legitimising the actions of the CIC in relation to the interests of other government entities, when setting strategic policy it may come late in the chain of negotiation and compromise that links CIC's senior staff to the central government-a prospect that also faces senior professional staff of the CIC. ${ }^{19}$

Similarly, we would argue that the CIC's commitment to the Santiago Principles is less about substantive policy than it is about claiming external legitimacy. We do not doubt Chinese commitment made to the process whereby the Principles were

\footnotetext{
18\%. Emblematic of this point is the official announcement made in November 2007 by the Vice Minister of Finance Li Yong concerning the intended investment strategy of the CIC. It is apparent from his statement that central government has direct control over strategic and tactical asset allocation, something not countenanced by many western governments when establishing their own sovereign wealth funds.

$19 \%$ In a related way, the International Advisory Council mimics similar arrangements in other sovereign wealth funds and meets the expectations of multilateral organisations in terms of promoting best practice. The IAC can be interpreted as a means of claiming external legitimacy for the CIC bringing together people with credible expertise and, most importantly, access to government policy making in the Americas, Asia, and Europe.
} 
conceived and agreed. Nor do we doubt the value of the principles in dampening political concerns expressed in the west about the lack of transparency and accountability of sovereign investment institutions when investing outside of their home jurisdictions. But we would contend that for the CIC its significance is more about matching its institutional form with international standards for the purpose of legitimacy than it is about facilitating effective investment decision-making. We would also contend that those that discount the significance of form underestimate the importance attached by the Chinese government to realising nation-state legitimacy through international norms and conventions. As such, the adoption of the Santiago Principles can be seen as part of a more general process of 'normalising' relationships with the west. But commitment to western institutional "forms" should not be taken to represent a similar functional allocation of powers and responsibilities consistent with the practice in many western investment agencies.

\section{CIC as a Strategic Investor}

When first mooted, it was hoped that the CIC would become a global investor on behalf of the Chinese government matching the investment practices of other large sovereign wealth funds. Because so much of Chinese foreign reserves are held in US dollars, a related expectation was that the CIC would place those assets in western securities markets in the manner consistent with other large, globally-focused diversified portfolio investors. Whether by implication or by virtue of the first steps taken in the establishment of the CIC, these expectations were fuelled by the active involvement of the $\mathrm{CIC}$ in the negotiation and proclamation of the Santiago Principles - the accepted norms 'governing' sovereign wealth fund investment practice brokered, in part, by the International Monetary Fund. So, for example, it was hoped that the CIC would rely upon global financial markets in a similar way to the Norwegian NBIM, even if there would be differences based upon the origin of assets and the likely significance of 'home bias' in the focus of investment portfolios.

If conceived as such, the CIC has not become a major portfolio investor content to take-up its share of global traded securities weighted by market capitalisation (within and between public markets). Its single largest holding, believed to be in the order of 
\$US120 billion, is the Central Huijin - core to the domestic banking system. ${ }^{20}$ Notable but much smaller investments were in US investment banks during the first stages of the global financial crisis. Stakes in Morgan Stanley, J C Flowers and Blackrock were acquired in late 2007 and early 2008, shortly after the formal establishment of the CIC and before the depth of the crisis became apparent to investors, governments, and the public at large. Having made high-profile investments in failing US banks, the CIC retreated to the sidelines of western financial markets. Hopes that the CIC might underwrite the liquidity of western financial markets in a reciprocal gesture matching Chinese reliance upon trade with the USA for economic development were not met. Arguably, the central government took fright at the trajectory of western markets, believing that their interests would not be protected by a US government bail-out of the financial system.

Looking back, it may be impossible to determine the motives and expectations of the central government during the first phase of the global financial crisis. Nonetheless, it is reasonable to suppose that expectations on both sides of the Pacific were not realised: the Chinese central government was not willing to contribute to financial market liquidity, and the US government could not be relied upon to protect the value of further Chinese investment in the US market as the crisis accelerated and deepened. Amplifying Chinese uncertainty, perhaps, was a realisation that the just-established CIC had neither the internal decision-making capacity nor the necessary trusted relationships with independent western expert investment advisors to be able to gauge the risks involved in further commitments to western financial institutions. ${ }^{21}$ If the Chinese government had relied upon their 'friends' in US banking and government circles for advice on taking positions in companies like Morgan Stanley, it is likely

\footnotetext{
20 . Huijin controls the Bank of China, the Industrial and Commercial Bank of China, and the China Construction bank. The Bank of China also has branches in the US. Without exemption from the Bank Holding Company Act, which provides for extensive operating and reporting requirements, it is believed that the central government would have had to rely upon foreign banks to manage their international (US) foreign currency reserves. In effect, the control of the Huijin gave the CIC and central government an operating arm at the core of western markets.

21 . A reader of a previous draft of this paper objected to this statement arguing that, surely, the CIC's stakes in US investment banks had given it this type of expertise. We note, however, that it widely acknowledged in the global banking industry that even having a 'majority' stake in an investment house is no guarantee of being part of the "inside story" on investment strategy and tactics. Here, the Chinese have held 'minority' stakes with little in the way of expertise and experience in 'governing' their relationships with western institutions to their advantage.
} 
that Chinese government officials then realised the crisis was far deeper than had been portrayed in confidential briefings.

By this account, any CIC plans to take forward a global portfolio investment programme in a manner consistent with western expectations were stillborn. See Table 1 where the CIC's US stock holdings by publicly-listed company and disclosed value are listed, indicating a limited number of relatively small investments in a selection of US companies. ${ }^{22}$ Note that there remain concerns about the availability of data from the CIC, and whether the data presented in Tables 1 and 2 do justice to the nature and scope of CIC investments in the USA and elsewhere. See, for example, the commentary by Z-Ben Advisors (2009) on the role and significance of Special Purpose Vehicles (SPV) for the CIC's US investments. It may be that the disclosure of US holdings through the US Securities Exchange Commission provides just a glimpse of the least controversial investments of the CIC, whereas the SPVs provide the CIC a means of holding back information on more aggressive acquisitions. Even so, there is little in the way of direct evidence that would support the argument that SPVs are important CIC instruments for US investment.

\section{[INSERT TABLE 1 ABOUT HERE]}

One implication from Table 1 is that the CIC has become a strategic investor by default. There is, however, a more positive account of the move to strategic investing. In this account, dollar-denominated assets were funnelled through the CIC to purchase significant stakes in the overseas finance, energy and resource sectors vital for future Chinese economic development (see Table 2). ${ }^{23}$ Therefore, the stakes taken in US finance firms were for its global reach through financial intermediaries rather than for their US market value. Here, the assumption that the CIC is a long-term investor

\footnotetext{
22\%. Both Table 1 and Table 2 are derived from the CIC's 13-F disclosure with the US Securities Exchange Commission (2009). See the comment provide by Rachel Ziemba "A glimpse inside the CIC's portfolio" February 7, 2010 published on the Roubini Global Economics website http://www.roubini.com/asia-monitor

23\%. See also The Wall Street Journal February 9, 2010 "What those CIC stake holding disclosures say about its strategy" (accessed February 9, 2010) where it is reported that the CIC typically held less than 1 per cent of the target companies' outstanding stock. It is suggested in the article that "the CIC is giving its in-house portfolio managers a chance to construct investing strategies” thereby gaining knowledge and experience that may be used some time latter. We are not so sure. See below.
} 
'explains' the selection of investment targets underpinned by an expectation that returns will be some premium on the US bond rate perhaps linked to the long-term rate of Chinese economic growth. Going further, it could be argued that China, lacking the financial institutions needed to sustain in economic development (in the manner suggested by King and Levine 1993a), made US banking investments for the implementation of a global investment strategy at the on-set of the global financial crisis — as it happens, these banks were available and at 'bargain' prices.

\section{[INSERT TABLE 2 ABOUT HERE]}

There are, in fact, three suppositions embedded in this argument: first, the supposition that the CIC is a long-term investor; second, the supposition that the expected real rate of return on US bonds is likely to be relatively low, especially if western markets are saturated with the offerings from similarly distressed countries and if inflation becomes a threat to the value of dollar-denominated holdings, and; third, the supposition that the expected rate of Chinese economic growth remains relatively high as the government manages the transition from a pure export-play to a more balanced growth policy with a greater role for domestic consumption (as suggested by Eichengreen and Park 2006). This is a reasonable argument, but it does assign the CIC a strategic investment role that may be beyond its responsibilities in relation to central government.

Another argument is also plausible. As in the first case, we contend that the Chinese government became disenchanted with US government policy-making and financial market performance. ${ }^{24}$ We assume that Chinese economic growth will continue to require enormous volumes of other countries' resources, and may be a better bet than the expected return on US dollar-denominated reserves. Hence, investments in resource-rich economies like Australia and Canada may be thought representative of a long-term policy of resource acquisition and security. Instead of thinking of the CIC as an investor governed by the long-term risk-adjusted rate of return on its investment portfolio, it may be better to think of the CIC as an arm of the Chinese government

\footnotetext{
24. See, for instance, commentary in The Wall Street Journal January 29, 2009 "Chinese Premier blames recession on US actions” by J. Dean, J. T. Areddy, and S. Ng and in The Los Angeles Times March 14, 2009 “China's Wen Jiabao concerned about stability of US debt” by D. Lee and B. Demick.
} 
just like other state-owned enterprises concerned with its resource needs and its status as a global power. As such, it is arguable that the Chinese government has sought to broaden the nature and scope of its bilateral relationships around the world so as to discount its reliance upon the USA as its 'sponsor' in the international community. When coupled with the investments made by the Chinese development bank in Africa, dollar-denominated assets invested through the CIC can be thought of as a means of realising economic and geopolitical advantage legitimised, perhaps, by an expressed but limited concern for the long-term rate of return on invested assets.

This argument does not, of course, exclude the possibility of the CIC returning to global financial markets as a portfolio investor once its own competence and capacity to sustain such a role is believed useful to the government. Nonetheless, our account of the CIC as a strategic investor suggests that the worst fears of China's critics inside and outside of the US Congress may be realised. Whereas prior to the financial crisis, the US had the financial clout to bind China to the original terms of the deal, 'normalizing' its role in the international community, the new realities of the $21^{\text {st }}$ century are that China need not honour those commitments. Indeed, such is the disarray in global financial markets that global strategic investment for long-term growth would seem to be an entirely reasonable strategy-albeit unavailable to the US and its Atlantic neighbours facing the costs of the crisis for the robustness and integrity of financial markets.

\section{Conclusions}

For a number of countries, their sovereign wealth funds are essential institutions for underwriting financial stability and economic growth. One lesson of the 1997 Asian financial crisis was that smaller countries exposed to the vagaries of global financial markets need sovereign wealth funds to act as insurers of last resort (Aizenman and Marion 2003). In this respect, in establishing sovereign wealth funds countries have sought to avoid reliance upon the multilateral institutions and in particular the International Monetary Fund. Whether nation-states have sought to protect their sovereignty or because reliance upon the International Monetary Fund brings with it terms and conditions that disturb domestic political alliances and commitments, selfinsurance is perceived to be the first best option (assuming little can be done to impose discipline on how global financial markets price countries currencies, debt, 
and economic growth prospects). If seen from a distance, one lesson of the recent global financial crisis is that a number of European countries including Ireland and the UK and the European Union may have benefited from the existence of such an institution.

For many countries that sponsor sovereign wealth funds, the assets of these institutions come from some natural resource or a distinctive national attribute of the global trade regime which results in the accumulation of "excess" wealth. So, for example, the Norwegian sovereign wealth fund owes its assets to the country's oil and gas reserves. In China's case, however, the assets of the CIC can be thought to be "earned" income from China's development strategy and, in particular, its exports to the United States of America. In this sense, these assets are not "windfalls" or "rents" derived from China's resource endowments; in fact, it's arguable that China's economic development including the rapid pace of urbanisation is driving the accumulation of resource "rents" in a number of countries and regions including Australia, Brazil, and East Africa. More to the point, China's accumulation of foreign earnings and the funding of the CIC are owed to the bilateral relationship struck between China and the USA in the early 1970s for reasons of mutual geopolitical advantage.

In this context, it is remarkable that there is so much discussion about so-called global "imbalances" in the context of the global financial crisis- the presumption being that resolution of these imbalances would return the global economy to a steady state (something like the last decade of the 20th century rather than the second decade of the 21st century). In fact, it is arguable that any such resolution would effectively create a bipolar world where China and the USA would have equal status as global superpowers, notwithstanding apparent differences in wealth and military might. Resolution of global imbalances would require, in part, the depreciation of the US dollar against the Chinese RMB and a retreat by China from an economic growth strategy based upon massive export to the US and western Europe and the de facto "regulation" of imports to China (see Eichengreen 2006; Feldstein 2008). Whereas rebalancing may provide the USA with a means of economic recovery from the predations of the global financial crisis, it would also reshape the relationship between 
China and the USA from one of dependency to one of bilateral equality underpinned by separate but contested spheres of global influence. ${ }^{25}$

In this paper, we have argued that China's relationship with the USA was part of the deal struck by the two countries mutual advantage: for China, it was part of a strategy of geopolitical re-alignment with the west (in relation to the USSR), matching the export-led development policies of its nearest neighbours while, for the USA, trade with China was a means of discounting the relationship between Communist allies and the establishment of a policy of US sponsorship of China in the international community of nations. As we suggest, geopolitics dominated the US trading relationship with China notwithstanding the apparent unease of some in the US Congress and the Senate about the economic consequences of unfettered export to the US market. Basically, geopolitics created the Chinese economic miracle and with it the prospect of a sovereign wealth fund or funds capable of affecting the path of global financial markets. Here is a rather different way of conceptualising the role of significance of the CIC-seeing it as derivative of geopolitics and embedded in the bilateral relationship between the USA and China which, perhaps to the surprise of the USA, has gone against expectations.

For these reasons, the CIC is less important than often imagined especially by those that would wish to "regulate" its actions by virtue of conditions imposed upon its disclosure and transparency. While no doubt an issue of significance when seen in the context of claims of legitimacy by other, much smaller, countries' sovereign wealth funds, the issue of Chinese legitimacy was, in the first instance, a geopolitical question resolved by the relationship brokered with the USA. Thereafter, as each and every review of that relationship occurred through what was once termed as China's most-favoured-nation status, geopolitics trumped concerns about Chinese domestic politics and policies just as it trumped anxieties about the potential impacts of unfettered export to the US consumer market. Put slightly differently, attempts to impose upon the CIC conditions or international norms and conventions such as the Santiago Principles have come too late in the evolving geopolitical relationship

\footnotetext{
$25 \%$ It should be stressed, though, that this 'recipe' for US prosperity is partial in that also required may be regulatory reform of the financial sector and the discounting of household indebtedness (Stiglitz 2009). Whether the is the political will for the US to realise such a reform agenda is one of the most important issues that will affect the long-term relationship between China and the USA.
} 
between China and the USA and the rest of the world. That is, the CIC is an expression of the deal done long ago for a special China-US relationship.

As we consider the policies and prospects for the CIC, it becomes apparent that it is deeply embedded in the structure of central government. Unlike many sovereign wealth funds, the CIC does not stand apart from its responsible ministries, claiming a measure of autonomy by virtue of the professional disciplines that proscribe standards of financial investment and the regulation of global financial markets. It is, like so much of Chinese central government, one element in a much larger commitment to maximising the rate of economic growth and China's claim for superpower status. If so, it is not surprising that its investments are largely strategic in nature rather than conforming to the standards of portfolio investment management that underpins its closest rivals in the international economy. Similarly, it should not be surprising that the CIC may not, in fact, do much more than observe the formal conventions associated with the Santiago principles-ultimately, its legitimacy is at once a domestic political issue and the function of China's increasing importance at the very centre of geopolitics, finance, and trade (compare with Truman 2007).

In these ways, our case study records the transformation of the USA from the surviving superpower of the second half of the 20th century into a nation-state that is arguably dependent upon its bilateral relationship with China as the other superpower of the 21st century (contra Callinicos 2009). As such, the CIC is a mere reflection of that transformation. 


\section{References}

Aizenman, J. and Lee, J. (2008). "Financial versus monetary mercantilism: long-run view of large international reserves hoarding”. The World Economy 31: 593-611.

Aizenman, J. and Marion, N. (2003). "The high demand for international reserves in the Far East: What's going on?” Journal of the Japanese and International Economies 17: 370-400.

Amiti, M. and Freund, C. (2010). "The anatomy of China's export growth". In China's Growing Role in World Trade, edited by Feenstra, R. C. and Wei, S-J. Chicago: University of Chicago Press, pp. 35-56.

Blonigen, B. A. and Ma, A. C. (2010). "Please pass the catch-up: the relative performance of Chinese and foreign firms in Chinese exports". In China's Growing Role in World Trade, edited by Feenstra, R. C. and Wei, S-J. Chicago: University of Chicago Press, pp. 475-509.

Bordo, M.D. (2005). “Historical perspective on global imbalances”. NBER Working Paper No. 11383.

Bowles, P. and Wang, B. (2006). “'Flowers and criticism': The political economy of the renminbi debate”. Review of International Political Economy 13(2): 233-57.

Bown, C. P. (2010). “China's WTO entry: antidumping, safeguards, and dispute settlement”. In China's Growing Role in World Trade, edited by Feenstra, R. C. and Wei, S-J. Chicago: University of Chicago Press, pp. 281-337.

Brannelly, J.M. (2002). “The United States’ grant of permanent normal trade status to China: a recipe for tragedy or transformation?” Suffolk Transnational Law Review 25(3): 565-85.

Brooks, S. G. and Wohlforth, W. C. (2008). World Out of Balance. Princeton: Princeton University Press.

Calleo, D. P. (2009). Follies of Power: America's Unipolar Fantasy. Cambridge: Cambridge University Press.

Callinicos, A. (2009). Imperalism and Global Political Economy. Cambridge: Polity Press.

Cheung, Y-W., Chinn, M. D. and Fujii, E. (2010). "China's current account and exchange rate”. In China's Growing Role in World Trade, edited by Feenstra, R. C. and Wei, S-J. Chicago: University of Chicago Press, pp. 231-71.

Chow, P. C. and Kellman, M. (1993). Trade: The Engine of Growth in East Asia. Oxford: Oxford University Press.

Clark, G. L. and Kim, W. B. (eds) (1996). The Asian NIEs in the Global Economy. Baltimore: Johns Hopkins University Press. 
Clark, G. L. and Monk, A. H. B. (2010). "Government of Singapore Investment Corporation (GIC): Insurer of last resort and bulwark of nation-state legitimacy" (forthcoming).

Clark, G. L. and Urwin, R. (2008). “Best-practice investment management”. Journal of Asset Management 9(1): 2-21.

Clark, G. L. and Wójcik, D. (2007). The Geography of Finance. Oxford: Oxford University Press.

Clark, I. (2005). Legitimacy in International Society. Oxford: Oxford University Press.

Cohen, B. J. (2009). "Sovereign wealth funds and national security: the great tradeoff”. International Affairs 85: 713-31.

Cooper, R.N. (2007). "Living with global imbalances”. Brookings Papers on Economic Activity 2: 91-107.

Dean, J. and Lovely, M. (2010). "Trade growth, production fragmentation, and China's environment”. In China's Growing Role in World Trade, edited by Feenstra, R. C. and Wei, S-J. Chicago: University of Chicago Press, pp. 429-69.

Deidda, L. and Fattouh, B. (2002). “Non-linearity between finance and growth”. Economic Letters 74: 339-45.

Dooley, M., Fernandez-Arias, E. and Kletzer, K. (1996). "Is the debt crisis history? Recent private capital inflows to developing countries”. World Bank Economic Review 10(1): 27-50.

Dooley, M., Folkerts-Landau, D. and Garber, P. (2004). “The revived Bretton Woods System”. International Journal of Finance and Economics 9: 307-13.

Eaton, S. (2009). “A Principal-Agent Analysis of China’s Sovereign Wealth System: Byzantine by Design.” Working Paper 0910. Research Center for International Finance.

Eichengreen, B. (2006). "Global imbalances: The new economy, the dark matter, the savvy investor, and the standard analysis.” Journal of Policy Modeling 28: 645-52.

Eichengreen, B. (2008). "Should there be a coordinated response to the problem of global imbalances? Can there be one?" DESA Working Paper 69.

Eichengreen, B. and Park, Y.C. (2006). “Global imbalances and emerging markets.” In Global Imbalances and the U.S. Debt Problem, edited by Teunissen, J.J. and Akerman, A. The Hague: Fondad, pp.14-44.

Feldstein, M.S. (2008). "Resolving the global imbalance: The dollar and the US saving rate." NBER Working Paper No. 13952. 
Garton, P. and Chang, J. (2005). "The Chinese currency: how undervalued and how much does it matter?” Australian Treasury, Economic Roundup 83-109. Available at: http://www.treasury.gov.au/documents/1042/PDF/08_RMBundervaluation.pdf.

Goldman Sachs. (2010). Global Economics Weekly. Issue No: 10/09, March $3^{\text {rd }} 2010$. London.

Goldstein, M. and Lardy, N. (2006). "China's Exchange Rate Policy Dilemma." American Economic Review 96(2): 422-26.

Grossman, G. M. and Helpman, E. (2005). "Outsourcing in a global economy". Review of Economic Studies 72: 135-59.

Grossman, G. M. and Rossi-Hansberg, E. (2008). “Trading tasks: a simple theory of offshoring”. American Economic Review 98: 1978-97.

Hall, P. A. and Soskice, D. W. (2001). Varieties of Capitalism: The Institutional Framework of Comparative Advantage. Oxford: Oxford University Press.

Hu, Y-W. (2010). "Management of China's Foreign Exchange Reserves: A Case Study of the State Administration of Foreign Exchange.” Mimeo.

Huang, H.-C., Lin, S.-C., Kim, D-H, Yeh, C.-C. (2010). ”Inflation and the financegrowth nexus". Economic Modelling 27(1): 229-36.

International Monetary Fund. (1993). World Economic Outlook. Washington DC.

Kim, D.-H. and Lin, S.-C. (2009). "Trade and growth at different stages of economic development”. Journal of Development Studies 45(8): 1211-24.

King, R.G. and Levine, R. (1993a). "Finance and growth: Schumpeter might be right”. Quarterly Journal of Economics 108(3): 717-37.

King, R.G. and Levine, R. (1993b). "Finance, entrepreneurship, and growth: theory and evidence”. Journal of Monetary Economics 32(3): 513-42.

Kissinger, H. (1982). Years of Upheaval. Boston: Little Brown.

Koppell, J. G. S. (2007). “Political control for China’s state-owned enterprises: lessons from America's experience with hybrid organizations”. Governance 20:25578.

Liang, Q. and Teng, J.-Z. (2006). "Financial development and economic growth: evidence from China”. China Economic Review 17: 395-411.

Merton, R. and Bodie, Z. 2005. "The design of financial systems: towards a synthesis of function and structure”. Journal of Investment Management 3: 1-23. 
Obstfeld, M. and Rogoff, K. (2005). "Global current account imbalances and exchange rate adjustments." At: http://elsa.berkeley.edu/ obstfeld/global_current.pdf.

Pregelj, V.N. (1996). "Most-Favored-Nation Status of the People's Republic of China." Washington: Congressional Research Service. At:

http://www.au.af.mil/au/awc/awcgate/crs/rl30225.pdf.

Reinhart, C.M., Rogoff, K.S. and Savastano, M.A. (2003). "Addicted to dollars." NBER Working Paper No. 10015.

Runciman, D. (2008). Political Hypocrisy: The Mask of Power, From Hobbes to Orwell and Beyond. Princeton: Princeton University Press.

Saaty, T.L. and Cho, Y. (2001). "The decision by the US congress on China's trade status: a multicriteria analysis.” Socio-Economic Planning Sciences 35: 243-52.

Scharpf, F. (1999). Governing in Europe: Effective and Democratic? Oxford: Oxford University Press.

Stiglitz, J. (2009). Freefall: Free Markets and the Sinking of the Global Economy. London: Allen Lane.

Summers, L. H. (2006). "Reflections on global account imbalances and emerging markets reserve accumulation”. L.K. Jha Memorial Lecture, Reserve Bank of India, Mumbai, India, March 24, 2006.

Truman, E.M. (2005). “Postponing global adjustment: an analysis of the pending adjustment of global imbalances”. Institute for International Economics, Washington D.C. Working Paper Series No. WP 05-6.

Truman, E.M. (2007). “The management of China’s international reserves: China and a SWF scoreboard.” Peterson Institute of International Economics:

Washington, DC.

Webber, M. J. (1996). “Changing places in east Asia”. In Asian NIEs and the Global Economy, edited by Clark, G. L. and Kim, W. B. Baltimore: Johns Hopkins University Press, pp. 22-51.

Wu, H.-L. Chen, C.-H. and Shiu, F.-Y. (2007). ”The impact of financial development and bank characteristics on the operational performance of commercial banks in the Chinese transitional economy”. Journal of Economic Studies 34(5): 401-14.

Xafa, M. (2007). “Global imbalances and financial stability”. Journal of Policy Modeling 29: 783-96.

Xie, T. (2006). “Congressional roll call voting on China trade policy”. American Politics Research 34(6): 732-58. 
Yao, S. (2000). "US permanent normal trade relations with China: what is at stake? a global analysis”. Policy Discussion Paper No. 0038. Adelaide University. Available at SSRN: http://papers.ssrn.com/sol3/papers.cfm?abstract_id=243550.

Z-Ben Advisors. (2009). “CIC’s US Disclosures: Reading Between the lines”. China Investment Management: Market Update. 
Figure 1. US Trade with PR China 1985-2008 (US\$)

\section{US Trade with China}

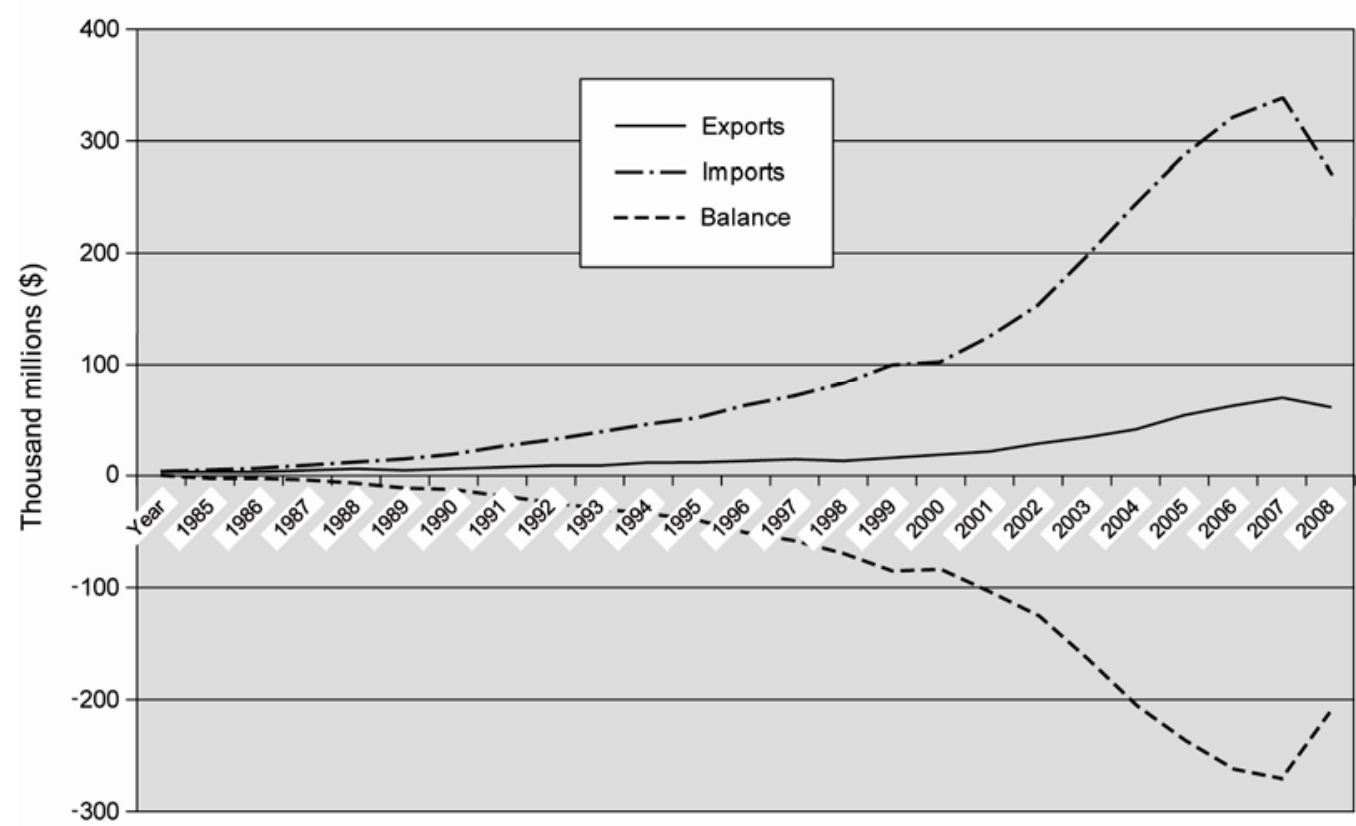

Source: Authors Analysis of IMF and PBOC data

Figure 2. USD Exchange Rates (normalised to base 1 1994)

USD Exchange Rates - Normalized to Base 1 in 1994

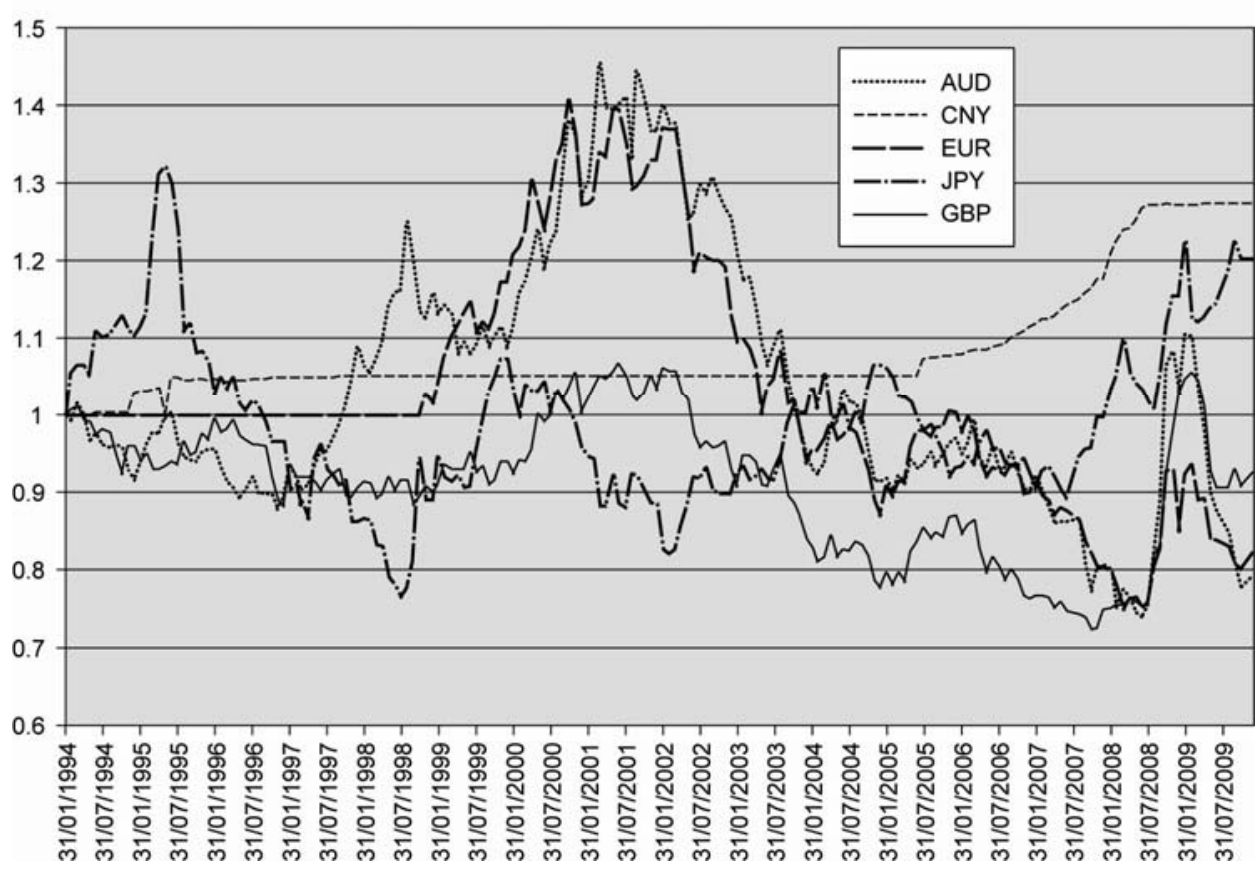

Source: Authors Analysis of IMF and PBOC data 
Figure 3. Schematic of CIC Governance (excluding Central Huijin Investment)

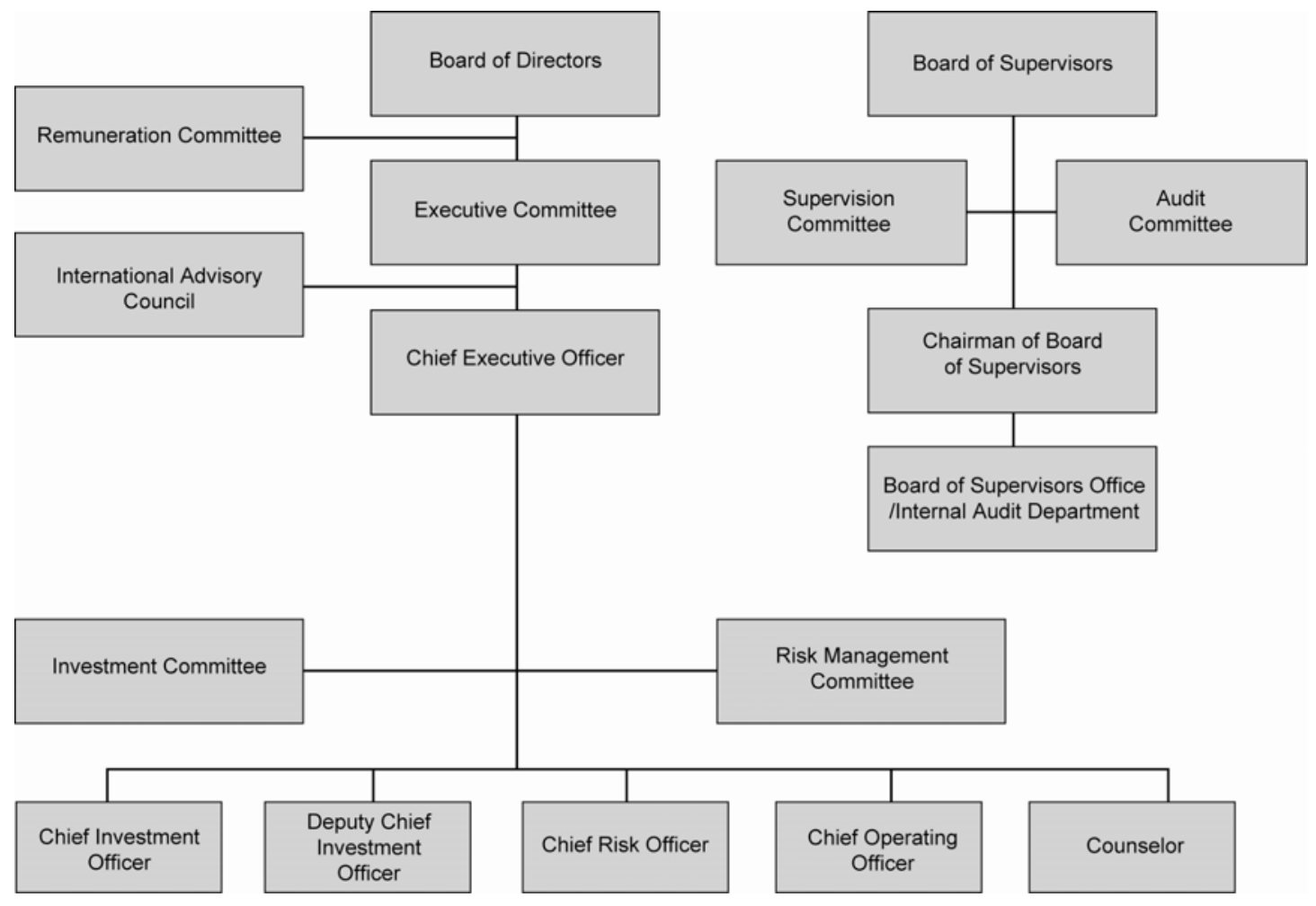

Source: China Investment Corporation, Annual Report 2008, page 17 


\begin{tabular}{|c|c|c|c|}
\hline \multicolumn{4}{|c|}{ Table 1. CIC: INVESTMENTS (2009) IN THE UNITED STATES } \\
\hline Company & $\begin{array}{l}\text { Reported } \\
\text { Value } \\
\text { (\$million) }\end{array}$ & Company & $\begin{array}{c}\text { Reported } \\
\text { Value } \\
\text { (\$million) }\end{array}$ \\
\hline Morgan Stanley & 5000 & $\begin{array}{l}\text { Gold Fields Ltd } \\
\text { New York Cmnty }\end{array}$ & 5 \\
\hline JC Flowers \& Co., LLC & 4000 & Bancorp & 4 \\
\hline Blackrock & 3000 & News Corp & 4 \\
\hline AES & 2151 & Anglogold Ashanti Ltd & 4 \\
\hline Oaktree & 1000 & Motorola Inc & 4 \\
\hline Apax & 956 & A123 Sys Inc & 4 \\
\hline GCL-Poly Energy & 710 & Lilly Eli \& Co & 4 \\
\hline & & American Eagle & \\
\hline Visa, Inc. & 100 & Outfitters & 3 \\
\hline Wells Fargo \& Co & 31 & Aetna Inc & 3 \\
\hline Citigroup & 30 & Comerica & 3 \\
\hline Bank of America & 20 & Fidelity & 3 \\
\hline AIG & 14 & Pulte Homes & 3 \\
\hline Johnson \& Johnson & 9 & UnitedHealth Group Inc & 3 \\
\hline Coca Cola & 9 & Pfizer Inc & 3 \\
\hline Merck \& Co & 7 & Abbott Labs & 3 \\
\hline Navistar Intl & 7 & $\begin{array}{c}\text { Tesoro Corp } \\
\text { Precision Castparts }\end{array}$ & 3 \\
\hline Kar Auction Svcs Inc & 7 & Corp & 3 \\
\hline Anadarko Pete Corp & 6 & D R Horton Inc & 3 \\
\hline Apple Inc & 6 & KLA-Tencor Corp & 3 \\
\hline Textron Inc & 6 & AMR Corp & 2 \\
\hline Smith Intl Inc & 6 & Health Net & 2 \\
\hline Potash Corp Sask Inc & 5 & Metlife Inc & 2 \\
\hline Chesapeake Energy Corp & 5 & Valero Energy Corp & 2 \\
\hline $\begin{array}{l}\text { Lincoln Natl Corp Ind } \\
\text { Burlington Northern }\end{array}$ & 5 & CSX Corp & 2 \\
\hline $\begin{array}{c}\text { Santa Fe } \\
\text { Freeport-McMoran }\end{array}$ & 5 & Sprint Nextel Corp & 2 \\
\hline Copper \& Gold & 5 & Goodyear Tire & 1 \\
\hline Terex Corp New & 5 & MEMC Electr Matls Inc & 1 \\
\hline Hartford Finl Svcs & 5 & Keycorp New & 1 \\
\hline Kinross Gold Corp & 5 & Expeditors Intl Wash & 1 \\
\hline Cummins Inc & 5 & & \\
\hline
\end{tabular}

Source: 13-F US Securities Exchange Commission (2009) 


\begin{tabular}{|c|c|c|c|c|}
\hline Company & $\begin{array}{l}\text { Purchase } \\
\text { Price } \\
\text { (\$million) }\end{array}$ & Industry & Country & Year \\
\hline Morgan Stanley & 5000 & Finance & USA & 2007 \\
\hline JC Flowers \& Co., LLC & 4000 & Finance & USA & 2008 \\
\hline Blackrock & 3000 & Finance & USA & 2007 \\
\hline AES & 2151 & Energy / Resources & USA & 2009 \\
\hline PT Bumi Resources & 1900 & Energy / Resources & Indonesia & 2009 \\
\hline Teck Resources & 1740 & Energy / Resources & Canada & 2009 \\
\hline Songbird Estates & 1400 & Real Estate & UK & 2009 \\
\hline Oaktree & 1000 & Finance & USA & 2009 \\
\hline Apax & 956 & Finance & UK & 2010 \\
\hline JSC KazMunaiGas & 939 & Energy / Resources & Kazakhstan & 2009 \\
\hline Noble & 850 & Energy / Resources & Hong Kong & 2009 \\
\hline GCL-Poly Energy & 710 & Energy / Resources & Hong Kong & 2009 \\
\hline $\begin{array}{l}\text { Poly Hong Kong } \\
\text { Iron Mining }\end{array}$ & 710 & Real Estate & $\begin{array}{l}\text { Hong Kong } \\
\text { Hong Kong / }\end{array}$ & 2009 \\
\hline $\begin{array}{l}\text { International } \\
\text { SouthGobi Energy }\end{array}$ & 700 & Energy / Resources & Mongolia & 2009 \\
\hline Resources & 500 & Energy / Resources & Canada & 2009 \\
\hline Goodman Group & 159 & $\begin{array}{c}\text { Real Estate } \\
\text { Transportation / }\end{array}$ & Australia & 2009 \\
\hline China Railway Group & 100 & Shipping & Hong Kong & 2007 \\
\hline Visa, Inc. & 100 & Finance & USA & 2008 \\
\hline
\end{tabular}

Source: Authors (from news articles). 